\title{
Jak się parać lingwistyką? Formalna analiza podejść wieloaspektowych
}

\author{
Wtodzimierz Lapis \\ Institute of Linguistics, Adam Mickiewicz University \\ ul. Międzychodzka 5, 60-371 Poznań, POLAND
}

lapisw@amu.edu.pl

\begin{abstract}
The paper proposes a formal classification of approaches to linguistic research. According to the presented calculation, one can engage in linguistic studies in forty-five ways, categorized into main approaches. The place and influence of pragmatics on this classification still seems relatively hazy.
\end{abstract}

\section{Wprowadzenie}

„Badać język” znaczy „prowadzić działania zmierzające do opisania jego mechanizmu”, na który to składają się:

a) reguły określające funkcjonowanie języka (ujęcie synchroniczne),

b) prawa determinujące jego rozwój (ujęcie diachroniczne).

Ponieważ są to ujęcia niezależne - tytułowe pytanie będziemy rozpatrywać oddzielnie w każdym $\mathrm{z}$ nich. Kierować je przy tym będziemy:

a) zarówno w odniesieniu do całego języka celem dokonania jego ogólnej formalnej analizy,

b) jak również w odniesieniu do poszczególnych wypowiedzi (słownych czy pisemnych) celem dokonania szczegółowej ich analizy formalnej.

\section{Omówienie ujęcia synchronicznego}

Prowadzić rozważania (opis i badania) w ujęciu synchronicznym oznacza czynić to w zakresie ograniczonym czasem (np. do teraźniejszości) i przestrzenią (a więc w odniesieniu do danego języka). W ujęciu tym funkcjonują trzy obszary obiektów językowych, wyznaczone przez uzus, normę i system danego języka. Przyjmujemy przy tym, że:

1. Przez system językowy rozumiemy ogół elementów językowych i wzorów konstrukcyjnych (reguł) ich łączenia.

2. Przez uzus (inaczej: zwyczaj językowy) rozumiemy te środki językowe, które są używane, a ich zakres wyznaczyć można w oparciu o tzw. poczucie językowe (intuicyjną świadomość językowa).

3. Z kolei norma to skodyfikowany (na potrzeby języka literackiego) uzus. W jej skład wchodzą nie tylko środki językowe używane, ale i zaaprobowane przez użytkownika danego języka na danym etapie jego rozwoju. 
Na podstawie powyższych definicji wnioskujemy, że między tymi obszarami zachodzą takie zależności, jak to zaznaczono na rys. 1. W oparciu o ich wzajemne ułożenie wyodrębniamy pięć klas językowych (A, B, C, D i E), obejmujących w sumie cały obszar rozważanego języka.

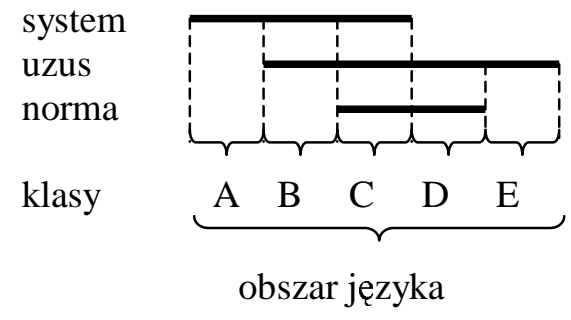

Rys. 1 Obraz języka
A - klasa elementów systemu potencjalnego

B - klasa elementów uzualno-systemowych

C - klasa elementów uzualno-normatywno-systemowych

D - klasa elementów uzualno-normatywnych

E - klasa elementów (czysto) uzualnych

Rysunek ten - jako ogólny - przedstawia pełny obraz języka. Można by go jednak odnosić niezależnie do fonetyki, semantyki i syntaktyki danego języka, otrzymując tym samym (niezależny w stosunku do zaprezentowanego podziału na klasy A, B, C, D i E) jego podział odpowiednio na fonetyczny obraz języka (ozn.: $J_{f o}$ ), semantyczny obraz języka (ozn.: $J_{\text {se }}$ ) i syntaktyczny obraz języka (ozn.: $J_{s y}$ ). Oczywiście, tym samym każda z klas A-E występowałaby w 3 wariantach w zależności od tego, w którym z tych obrazów jest rozważana. Do ich oznaczania wykorzystujemy indeksy dolne identyczne z powyższymi, pisząc je przy odpowiedniej klasie. Tak np. $B_{s y}$ oznacza klasę elementów uzualno-systemowych syntaktycznego obrazu języka.

Obraz języka zaprezentowany na rys. 1 można analizować również od innej strony. Przyjrzyjmy się występującemu w nim pojęciu „norma”. Tradycyjnie rozumiemy ją jako „wskazówkę właściwego działania lub sądzenia”. W filozofii zwykło się odróżniać normy moralne, estetyczne i logiczne. Odpowiednie wyznaczone przez nie dyscypliny (jak więc widać nie bez przyczyny noszące nazwę normatywnych) to: etyka, estetyka i logika. Stąd też obraz języka można rozważać również w niezależnym od wyżej zaprezentowanego aspekcie etycznym (jego następstw, intencji), estetycznym (piękna budowy i ,przyjemnego odbioru”) oraz logicznym (poprawna budowa). Oczywiście, każdy z tych aspektów można rozpatrywać w odniesieniu do całego obrazu języka (otrzymując tym samym obrazy oznaczane odpowiednio symbolami $J^{e t}, J^{e s}$ i $J^{l o}$ ).

W sumie daje to nam 9 klas - podejść do badanego języka:

$$
\begin{aligned}
& J_{f o}^{e t}, J_{f o}^{e s}, J_{f o}^{l o}, \\
& J_{s y}^{e t}, J_{s y}^{e s}, J_{s y}^{l o}, \\
& J_{s e}^{e t}, J_{s e}^{e s}, J_{s e}^{l o}
\end{aligned}
$$

(np. $J_{f o}^{e t}$ oznacza fonetyczny obraz języka rozważany w aspekcie etycznym).

Każda z tych 9 klas ma 5 klas wewnętrznych (A, B, C, D i E). Tak np. $J_{f o}^{e t}$ składa się z $A_{f o}^{e t}$, $B_{f o}^{e t}, \quad C_{f o}^{e t}, \quad D_{f o}^{e t}$ i $E_{f o}^{e t}$ (gdzie np. $B_{f o}^{e t}$ oznacza klasę elementów uzualno-systemowych fonetycznego obrazu języka rozważanego w aspekcie etycznym).

Prowadzić badania w językoznawstwie synchronicznym można więc całościowo lub zawężając je do punktu, wektora, czy też płaszczyzny 3-wymiarowej kostki $(A, B, C, D, E)_{(f o, s y, s e)}^{(e t, e s, l o)}$ (jest to tzw. kostka synchroniczna), przy czym można łącznie rozpatrywać też kilka punktów, wektorów, czy też płaszczyzn. Tak np. grupując odpowiednio klasy A-E, otrzymujemy:
$(A \div C)_{(f o, s y, s e)}^{(e t, e s, l o)}-$ opis ustalonego systemu,
$(B \div E)_{(f o, s y, s e)}^{(e t, e s, l o)}$ - opis ustalonego uzusu,
$(C \div D)_{(f o, s y, s e)}^{(e t, e s, l o)}-$ opis ustalonej normy. 


\section{Omówienie ujęcia diachronicznego}

Prowadzić badania w ujęciu diachronicznym - to prowadzić badania w zakresie opisanym w ostatnim akapicie, jednak dodatkowo w odniesieniu czasowym i/lub przestrzennym. Do trzech wyszczególnionych już wymiarów dochodzą więc nam jeszcze dwa, spośród których co najmniej jeden musi być użyty. Wtedy zachowując wszystkie wybrane parametry z trzech wymiarów kostki synchronicznej - przebiegamy oś czasu i/lub przestrzeni i patrzymy, jak zmieniają się wtedy wartości ustalonych parametrów.

\section{Charakterystyka dziedzin szczegółowych}

Może się wydawać, że etyka nie ma nic wspólnego z językiem. Otóż normy etyczne naruszyć można myślą, mową, uczynkiem, czy też zaniedbaniem. Usuwając na bok kwestię „,czy człowiek myśli za pomoca języka" pozostaje nam, że dokonać tego można określonym aktem mowy, czy też jego brakiem (nie wykonaniem go, podczas gdy powinniśmy to zrobić). Jeśli już go wykonamy, to niewłaściwy przekaz pod względem etycznym będzie miał miejsce wtedy, gdy poprzez odpowiednią manipulację fonetyka, semantyką czy syntaktyką (w wyniku użycia formy nieadekwatnej lub wieloznacznej) spowodujemy niewłaściwy odbiór przekazu, który - w takim przypadku jako spowodowany świadomie - jest etycznie niewłaściwy. Jest kłamstwem i może nieść z tego względu dalsze następstwa natury etycznej.

Przypatrzmy się z kolei związkowi estetyki z językiem. Normy estetyczne w języku naruszyć można zarówno w piśmie, jak i w mowie. Będzie miało to miejsce wtedy, gdy w zakresie fonetyki, semantyki czy syntaktyki naruszy się reguły piękna (konstrukcji, tonu, intonacji, zapisu, rytmu, rymu $\mathrm{i}$ in.).

Najbardziej znaczący wydaje się być jednak związek logiki z językiem. W zakresie semantyki - mamy bowiem rozważanie poprawności logicznej zdań i całych wypowiedzi (w tym cała teoria gramatyk generatywno-transformacyjnych); w zakresie semiotyki - zagadnienie poprawności użycia poszczególnych słów (chociażby ze względu na ich wieloznaczność znaczeniowa), badanie struktury argumentacji; w zakresie fonetyki np. badanie wpływu sposobu akcentowania na znaczenie wypowiedzi. W następstwie faktu, że główny prąd badań poszedł właśnie tym torem, wyżej opisane zagadnienia (związku lingwistyki $\mathrm{z}$ etyką i estetyka) są w znacznej mierze zaniedbane w badaniach naukowych.

Na uwagę zasługuje tu jeszcze zagadnienie miejsca pragmatyki w lingwistyce. Jak sądzę, można by ją określić jako naukę o pewnym ukierunkowaniu wyżej wymienionych dziewięciu podejść do języka. Oczywiście, ukierunkowanie to musi być nastawione na osiagnięcie określonego celu. $\mathrm{Z}$ tego powodu może powodować nie spełnianie pewnych norm (np. etycznych, estetycznych), jeśli tylko w określonej grupie odbiorców działanie takie byłoby efektywne. Po prostu pragmatyzm kłóciłby się tu z poprawnością normatywna, a działanie pragmatyczne odbywałoby się na zasadzie „cel uświęca środki” (z którą to piszący te słowa się nie zgadza). 